\title{
POST-ACTIVATION POTENTIATION AND FATIGUE OF QUADRICEPS MUSCLE AFTER CONTINUOUS ISOMETRIC CONTRACTIONS AT MAXIMAL AND SUBMAXIMAL INTENSITIES
}

\author{
Nerijus Masiulis, Albertas Skurvydas, Sigitas Kamandulis, Jūratė Kudirkaitė, Vytautas Sukockas, \\ Edmundas Valys, Vilma Jurevičienè, Lina Kamandulienė \\ Lithuanian Academy of Physical Education, Kaunas, Lithuania
}

Nerijus Masiulis. Doctor of Biomedical Sciences. Research interests: acute adaptation of skeletal muscle during and after short time exercise.

\begin{abstract}
The dominance of fatigue or post-activation potentiation (PAP) depends on the type, intensity, and duration of exercise and duration of the recovery before contractility is tested. Although the decrease in PAP magnitude with decreased exercise intensity is well documented (Vandervoort et al., 1983; Behm et al., 2004), it is not clear how PAP and fatigue influences the contractile properties of skeletal muscle when exercise is of different intensity but with the same amount of work performed. Thus it is important to understand the manifestation of PAP and fatigue of skeletal muscle after continuous maximal and submaximal contractions but with the same amount of work performed.
\end{abstract}

Eight healthy untrained men (age 23-27 years, mass $83.5 \pm 5.4 \mathrm{~kg}$ ) performed maximal sustained isometric knee extension for $30 \mathrm{~s}$ (MVC-30 s) and on the other occasion the same subject performed sustained isometric knee extension for $60 \mathrm{~s}$ at $50 \%$ of maximal $(50 \% \mathrm{MVC}-60 \mathrm{~s})$. We assumed that the amount of performed work was the same during both MVC-30s and 50\% MVC-60 s exercises. The experimental order was randomized. The contractile properties of quadriceps muscle evoked by electrical stimulation at $1 \mathrm{~Hz}(P 1), 10 \mathrm{~Hz}(P 10), 20 \mathrm{~Hz}(P 20)$, and $50 \mathrm{~Hz}(P 50)$ as well as contraction time $(C T)$ and relaxation time $(R T)$ of single twitch $(P 1)$ and $E M G_{r m s}$ of v. lateralis muscle were recorded before and immediately after the exercises (0 min) and 1, 2, and 3 min following the exercises.

A significantly greater potentiation ( $p<0.05)$ of $P 1$ was observed after 30-s MVC (MVC-30 s) compared with the 60-s MVC (50\% MVC-60 s) immediately after exercise and at 1 min of recovery. No changes in $P 1$ contraction time (CT) were observed during 3 min recovery period, however half relaxation of $P 1(1 / 2 R T)$ was more prolonged $(p<0.05)$ immediately after 50\% MVC-60 s exercises. Moreover, immediately and 1 min post exercise the P 10 force after $M V C-30 \mathrm{~s}$ exercise was higher $(p<0.05)$ compared to $50 \% \mathrm{MVC}-60 \mathrm{~s}$ exercise. No differences between $M V C-30 \mathrm{~s}$ and 50\% MVC-60 s exercises were observed at high stimulation frequencies, maximal voluntary contraction force $(M V C)$ as well as for $E M G_{r m s}$ values during 3 min recovery period.

The main finding of the present study was that PAP was observed after both maximal and submaximal intensity exercises when the same amount of work was performed. The more intensively exercise is performed, the more PAP offsets fatigue straight after exercise (maximal intensity); while after submaximal exercise PAP becomes more evident only during the recovery period.

Keywords: skeletal muscle, isometric exercise, maximum voluntary contraction, recovery.

\section{INTRODUCTION}

T The performance of skeletal muscle is affected by its contractility history. While fatigue will impair performance, post-activation potentiation (PAP) acts to improve performance (Vandervoort et al., 1983; Baudry, Duchateau, 2004; Masiulis et al., 2006). The dominance of fatigue or PAP depends on the type, intensity, and duration of exercise and duration of the recovery before contractility is tested. It has been shown

that intense and very short (about $5-10 \mathrm{~s}$ ) isometric contractions induce PAP, i. e., an increase in contractile force evoked by a single twitch and/or low-frequency stimulation, lasting for 5-10 min (Houston, Grange, 1990). Temporal characteristics of contraction are also affected in a way that force development and relaxation occur at a faster rate (O'Leary et al., 1997; Hamada et al., 2000). The magnitude of PAP is greater in muscles 
with highest proportion of type II muscle fibers (Vandervoort et al., 1983; Hamada et al., 2000). Phosphorylation of myosin regulatory light chains has been implicated as the underlying mechanism of PAP in human skeletal muscles (Houston, Grange, 1990).

It was shown that voluntary contractions at $<75 \%$ MVC produced little or no potentiation. It was concluded that maximal (vs. submaximal) voluntary contractions lasting approximately $10 \mathrm{~s}$ cause the greatest twitch potentiation (Vandervoort et al., 1983). The fact that potentiation can occur during submaximal exercise with leg extensors in humans is supported by P. D. Gollnick et al. (1974), who observed that fast-twitch fibres are used at lower force levels than generally believed, and by the previous work by O. M. Rutherford et al. (1986), who also observed potentiation early in repetitive exercise performed at 30 and $45 \%$ MVC.

Although the decrease in PAP magnitude with decreased exercise intensity is well documented (Vandervoort et al., 1983; Behm et al., 2004), it is not clear how PAP and fatigue influences the contractile properties of skeletal muscle when exercise is of different intensity but with the same amount of work performed. Thus it is important to understand the manifestation of PAP and fatigue of skeletal muscle after continuous maximal and submaximal contractions with the same amount of work performed.

\section{METHODS}

Subjects. Eight healthy untrained men (aged $23-27$ years, mass $83.5 \pm 5.4 \mathrm{~kg}$ ) gave their informed consent to participate in this study. The subjects were physically active but did not take part in any formal physical exercise or sport program. Each subject read and signed written informed consent form consistent with the principles outlined in the Declaration of Helsinki.

Force Measurements. The equipment and technique used for measuring force were the same as used in the previous studies (Skurvydas, Zachovajevas, 1998; Masiulis et al., 2006). Briefly, before performing explosive strength training session the subjects were seated in a steel framed straight-backed adjustable chair and appropriate adjustments were made to ensure an optimal riding position. A seatbelt attached to the side of the chair passed around the subject's waist and chest to firmly secure the pelvis and upper body for minimizing uncontrolled movements. The right leg was clamped in a force-measuring device with the knee kept at an angle of $90^{\circ}$ (full extension being $180^{\circ}$ ) during the whole experiment. A 6-cm-wide plastic cuff, placed around the right leg just proximal to the malleoli, was tightly attached to a linear variable differential transducer. The output of the transducer, proportional to isometric knee extension force, was amplified and digitized at a sampling rate of $1 \mathrm{kHz}$ by a 12-bit analogue-to-digital converter incorporated in a personal computer. The digitized signal was stored on a hard disk for subsequent analysis. The output from the force transducer was also displayed on a voltmeter in front of the subject. Maximal voluntary contraction (MVC) force was determined.

Electrical Stimulation. A high-voltage stimulator (MG 440, Medicor, Budapest, Hungary) was used to deliver electrical stimuli to the quadriceps muscle through surface electrodes $(9 \times 18 \mathrm{~cm})$ padded with cotton cloth and soaked in saline solution. One stimulation electrode was placed just above the patella, while another one covered a large portion of the muscle belly in the proximal third of the thigh. The electrical stimulation was always delivered in trains of square wave pulses of 1-ms duration (voltage $150 \mathrm{~V}$, which induced approximately $60-80$ percent of MVC). To maximize recruitment of fibres, the highest possible stimulation voltage was employed. The subjects were familiarized with electrical stimulation during the introductory visit before the onset of experiments. We measured the contractile force of the quadriceps muscle, evoked by electrical stimulation at 1 (P 1), 10 (P 10), 20 (P 20), and 50 (P 50) Hz (the duration of each electrical stimulation series was $1 \mathrm{~s}$ ). The rest interval between muscle electrical stimulation was $3 \mathrm{~s}$. Contraction time (CT) and relaxation time (RT) of single twitch (P1) of quadriceps muscle was also recorded.

Electromyography. The electromyogram (EMG) was recorded only during voluntary contraction. Two Ag-AgCl electrodes (FE1 surface electrode, Medicor, Budapest, Hungary) were used. The electrodes were placed over the vastus leteralis muscle approximately $15-\mathrm{cm}$ proximal to the superior border of the patella, and approximately $3-\mathrm{cm}$ proximal to the distal stimulation electrode. The electrodes were of rectangular shape $(5 \times 10 \mathrm{~mm})$ and were glued to a plastic plate to maintain a distance of $10 \mathrm{~mm}$ between 
them. The skin was shaved and cleaned with ethanol, and the electrodes, covered with electrode jelly, were placed over the muscle. The EMG signals (amplified $\times 2500$ and bandpass filtered between 10 and $1000 \mathrm{~Hz}$; MG 440, Medicor, Budapest, Hungary) were analogue-to-digital converted (12 bit) at a sampling rate of $2500 \mathrm{~Hz}$ and stored on hard disk for subsequent analysis. Sample duration of $2 \mathrm{~s}$ was always used. During calculations of electromyogram root mean square $\left(E M G_{r m s}\right)$, adjustments for the resting signal level were made (Mathiassen, Winkel, 1990; Ratkevicius et al., 1995). The resting $\mathrm{EMG}_{\mathrm{rms}}$ was evaluated at the beginning of each experiment after the electrodes were positioned on the vastus lateralis muscle.

Experimental Protocol. Two experiments were carried out with 1 week interval in between them. Before the experiments the subject performed a 5 min warm-up and was seated in the experimental chair right afterwards. After $5 \mathrm{~min}$, the initial contractile properties of muscle (Ini) were recorded in the following sequence: P 1, P 10, P 20, P 50 and MVC (MVC was reached twice with 1 min rest in between) at knee angle of $90^{\circ}$. During MVC, the $2 \mathrm{~s}$ $\mathrm{EMG}_{\mathrm{rms}}$ of $\mathrm{v}$. lateralis muscle was recorded when the contraction force reached plateau. To determine the impact of the exercise intensity on neuromuscular system, we chose two exercises of different intensity but with the same amount of work performed. The subject performed maximal sustained isometric knee extension for $30 \mathrm{~s} \mathrm{(MVC-30} \mathrm{s)} \mathrm{and}$ on the other occasion the same subject performed sustained isometric knee extension for $60 \mathrm{~s}$ at $50 \%$ of maximal ( $50 \%$ MVC- $60 \mathrm{~s})$. We assumed that the amount of performed work was the same during both MVC-30 s and 50\% MVC-60 s exercises. The experimental order was randomized. The contractile properties of quadriceps muscle and EMG of v. lateralis muscle were recorded immediately after the exercise ( $0 \mathrm{~min}$ ) and 1,2 , and $3 \mathrm{~min}$ following the exercise.

Statistics. The results obtained have been processed using the methods of mathematical statistics by calculating the means $(\overline{\mathrm{x}})$ and standard deviations of mean $( \pm \mathrm{SD})$. The differences for repeated measures in mean values were evaluated by using Student's t-test for paired data. The level of significance of the difference between arithmetic means was considered relevant when the $p$ value was less than 0.05 . The analyses were done making use of the Microsoft Excel 2000.

\section{RESULTS}

The twitch force (P 1) was significantly elevated above pre-exercise value immediately (0 min) after 30-s MVC (MVC-30 s) exercise $(\mathrm{p}<0.05)$, but it remained unchanged after 60 -s MVC (50\% MVC-60 s) exercise when compared with an initial value (Fig. 1). Already at $1 \mathrm{~min}$, P 1 was potentiated after both exercises and remained elevated until 3 min of recovery period $(p<0.05)$ (Fig. 1). Statistically significant differences $(p<0.05)$ were observed for P 1 immediately $(0 \mathrm{~min})$ and $1 \mathrm{~min}$ following the exercises after MVC-30 s and 50\% MVC-60 s were compared (Fig. 1).

No changes in twitch CT were observed during 3 min recovery period after MVC-30 $\mathrm{s}$ and $50 \%$ MVC- 60 s exercises $(p>0.05)$. Twitch $1 / 2$ RT was prolonged $(\mathrm{p}<0.05)$ immediately after MVC-30 s and 50\% MVC-60 s exercises, but no changes were observed at $1 \mathrm{~min}$ after exercises
Fig. 1. The time-course of changes in $P 1$ after sustained MVC for $30 \mathrm{~s}$ at maximal (MVC-30 s, solid bars) and for $60 \mathrm{~s}$ at submaximal $(50 \% \mathrm{MVC}$ $60 \mathrm{~s}$, open bars) intensities, right after $(0 \mathrm{~min})$ and following 1,2 and $3 \mathrm{~min}$ of recovery

Note. The dashed line indicates the initial mean level (100\%). P1 - muscle contraction force at a stimulation rate of $1 \mathrm{~Hz}$; Values are means \pm SD. Statistically significant differences from initial are indicated as: * $-\mathrm{p}<0.05$; \# - significant $(\mathrm{p}<0.05)$ difference between MVC-30 s and 50\% MVC-60 s $(\mathrm{n}=8)$.

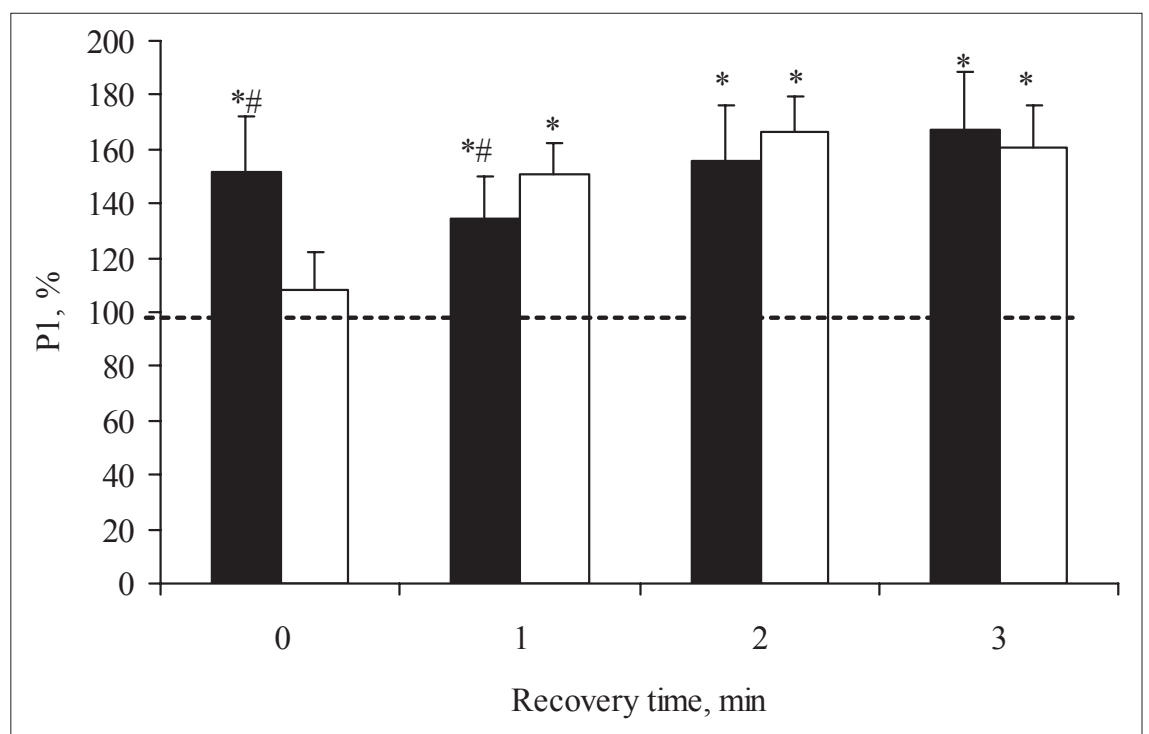



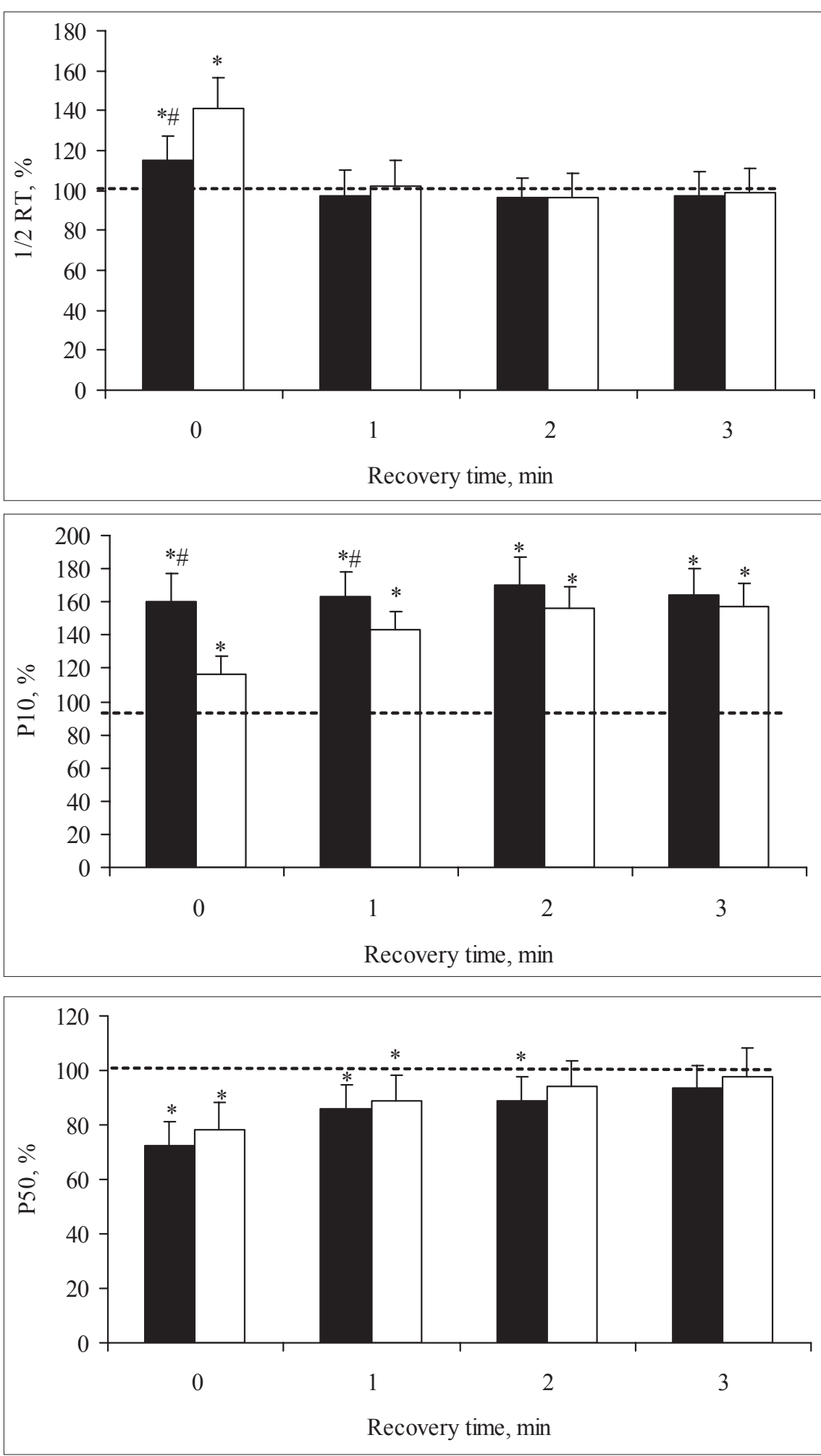

Fig. 2. Half relaxation time $(1 / 2 \mathrm{RT})$ of single twitch (P 1) after MVC for $30 \mathrm{~s}$ at maximal (MVC-30 s, solid bars) and for $60 \mathrm{~s}$ at submaximal $(50 \%$ MVC$60 \mathrm{~s}$, open bars) intensities, right after $(0 \mathrm{~min})$ and following 1,2 and $3 \mathrm{~min}$ of recovery

Note. The dashed line indicates the initial mean level (100\%). Values are means \pm SD. Statistically significant differences from initial are indicated as: $*$ - $\mathrm{p}<0.05$; \# - significant $(\mathrm{p}<0.05)$ difference between MVC-30 s and 50\% MVC-60 s ( $\mathrm{n}=8)$.

Fig. 3. The time-course of changes in P 10 after sustained MVC for $30 \mathrm{~s}$ at maximal MVC-30 s, solid bars) and for $60 \mathrm{~s}$ at submaximal $(50 \%$ MVC$60 \mathrm{~s}$, open bars) intensities, right after $(0 \mathrm{~min})$ and following 1,2 and $3 \mathrm{~min}$ of recovery

Note. The dashed line indicates the initial mean level $(100 \%)$. P 10 - muscle contraction force at a stimulation rate of $10 \mathrm{~Hz}$; Values are means \pm SD. Statistically significant differences from initial are indicated as: * $-\mathrm{p}<0.05, \#-$ significant $(\mathrm{p}<0.05)$ difference between MVC- $30 \mathrm{~s}$ and $50 \%$ MVC- $60 \mathrm{~s}(\mathrm{n}=8)$.

Fig. 4. The time-course of changes in $\mathbf{P} \mathbf{5 0}$ after sustained MVC for $30 \mathrm{~s}$ at maximal (MVC-30 s, solid bars) and for $60 \mathrm{~s}$ at submaximal $(50 \%$ MVC- $60 \mathrm{~s}$, open bars) intensities, right after ( $0 \mathrm{~min})$ and following 1,2 and $3 \mathrm{~min}$ of recovery

Note. The dashed line indicates the initial mean level $(100 \%)$. P 50 - muscle contraction force at a stimulation rate of $50 \mathrm{~Hz}$; Values are means \pm SD. Statistically significant differences from initial are indicated as: $*-p<0.05(n=8)$. compared to the control value (Fig. 2). Right after $50 \% \mathrm{MVC}-60 \mathrm{~s}$ exercise (at $0 \mathrm{~min}$ ), $1 / 2 \mathrm{RT}$ was significantly prolonged $(\mathrm{p}<0.05)$ when compared to the MVC-30 s exercise (Fig. 2).

Following both fatiguing tasks the response evoked by $10 \mathrm{~Hz}$ (Fig. 3) was significantly affected $(\mathrm{p}<0.05)$ at every time point during 3 -min recovery. Furthermore, immediately and $1 \mathrm{~min}$ post exercise the P 10 force after MVC-30 s exer- cise was significantly higher $(\mathrm{p}<0.05)$ compared to $50 \%$ MVC-60 s exercise (Fig. 3). It should be emphasized that $\mathrm{P} 1$ and $\mathrm{P} 10$ values at $3 \mathrm{~min}$ after 50\% MVC-60 s were significantly higher $(\mathrm{p}<0.05)$ than the values immediately $(0 \mathrm{~min})$ after 50\% MVC-60 s exercise (Fig. 1, 3).

The $\mathrm{P} 50$ response (Fig. 4) was depressed immediately after MVC-30 s exercise and did not recover to its initial level by $2 \min (\mathrm{p}<0.05)$. A similar 
Fig. 5. The time-course of changes in MVC after sustained MVC for $30 \mathrm{~s}$ at maximal (MVC-30 s, solid bars) and for $60 \mathrm{~s}$ at submaximal $(50 \%$ MVC$60 \mathrm{~s}$, open bars) intensities, right after $(0 \mathrm{~min})$ and following 1,2 and $3 \mathrm{~min}$ of recovery

Note. The dashed line indicates the initial mean level (100\%). Values are means \pm SD. Statistically significant differences from initial are indicated as: $*-\mathrm{p}<0.05$ $(n=8)$.

Fig. 6. The time-course of changes in $\mathbf{E M G}_{\text {rms }}$ after sustained $\mathbf{M V C}$ for $30 \mathrm{~s}$ at maximal (MVC-30 s, solid bars) and for $60 \mathrm{~s}$ at submaximal $(50 \%$ MVC$60 \mathrm{~s}$, open bars) intensities, right after (0 min) and following 1, 2 and $3 \mathrm{~min}$ of recovery

Note. The dashed line indicates the initial mean level (100\%). $\mathrm{EMG}_{\mathrm{rms}}$ - electromyogram root mean square. Values are means \pm SD. Statistically significant differences from initial are indicated as: $*$ - $\mathrm{p}<0.05(\mathrm{n}=8)$.
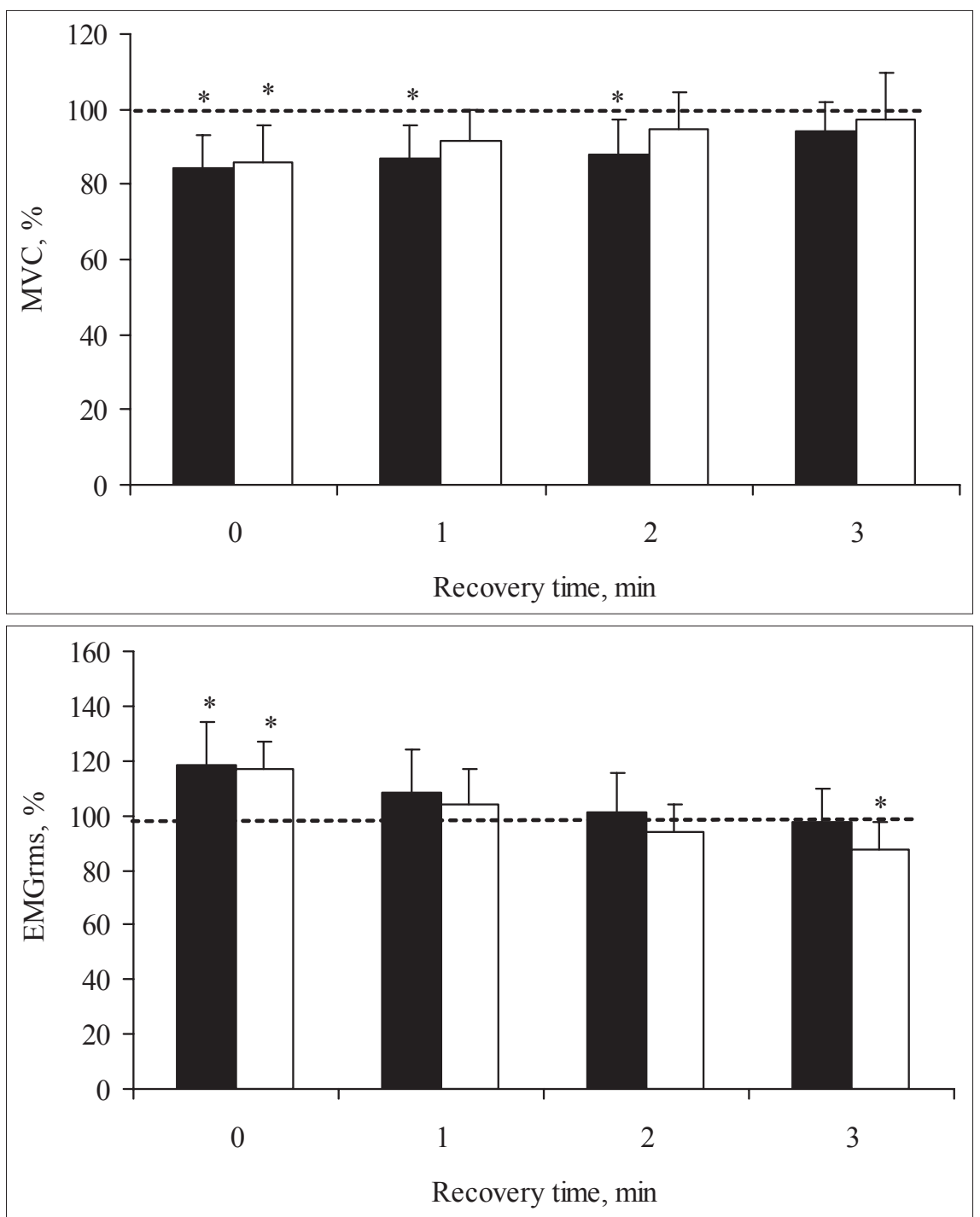

observation was after 50\% MVC-60 s exercise, but force at P 50 recovered within 2 min (Fig. 4).

Both exercise protocols resulted in a decreased MVC force (Fig. 5). The depression in MVC persisted throughout the 2-min recovery period after MVC-30 s $(\mathrm{p}<0.05)$ and for $1 \mathrm{~min}$ after $50 \%$ MVC-60 s $(\mathrm{p}<0.05)$. No differences between MVC-30 s and 50\% MVC-60 s exercises were observed at high stimulation frequencies as well as in MVC (Fig. 4, 5). Values for $\mathrm{EMG}_{\mathrm{rms}}$ recorded immediately after both exercises were significantly augmented, while at 3 min after 50\% MVC- $60 \mathrm{~s}$ exercise were significantly reduced $(\mathrm{p}<0.05)$ (Fig. 6).

\section{DISCUSSION}

The main finding of this study was that PAP was observed after both maximal and submaximal intensity exercises when the same amount of work performed. Furthermore, the more intensively ex- ercise is performed, the more PAP offsets fatigue straight after exercise (maximal intensity); while after submaximal exercise PAP becomes more evident only during the recovery period.

Greater prolongation of relaxation time and force depression after the 50\% MVC-60 s exercise at 0 min could be induced by various metabolic products. Prolongation of relaxation would logically be an effective mechanism to combat the effects of fatigue by increasing the time for $\mathrm{Ca}^{2+}$ release to optimize cross-bridge kinetics. Twitch properties have been reported to be affected by $\mathrm{H}^{+}$accumulation and increases in ADP (Cady et al., 1989). It was pointed out, that the slowing of relaxation increasing the degree of fusion of low stimulation tetanus. This process, which was thought to minimize fatigue was called "muscle wisdom" (Marsden et al., 1983). Following $50 \%$ MVC- $60 \mathrm{~s}$ fatiguing task, $1 / 2 \mathrm{RT}$ of $\mathrm{P} 1$ was more prolonged compared to MVC-30 s (Fig. 2), therefore after 50\% MVC-60 s greater "muscle 
wisdom" occurred. Also the fact that after 50\% MVC-60 s P 10 was higher than P 1 immediately after exercise, can prove that the "muscle wisdom" occurred (Fig. 1, 3). Muscle wisdom is a description for the process by which the activation rates of motor units are modulated by the CNS to optimize force during sustained contractions (Marsden et al., 1983).

Specifically, C. D. Marsden and colleagues (1983) argued that during a prolonged contraction the contractile rate of the muscle slows, allowing lower activation rates to produce the maximal force from the muscle during fatigue. It has been shown that during MVC held for at least $60 \mathrm{~s}$, there was a gradual decline in force, a progressive decline in means firing rates of motor units (Bigland-Ritchie et al., 1983; Marsden et al., 1983), and a decline in contractile speed (Bigland-Ritchie, 1993). It has been suggested that as the muscle fatigues, motor units decrease their firing rates to match the decreasing contractile speed so that lower frequencies, which are less fatiguing, could still generate relatively higher forces (Marsden et al., 1983; Enoka, Stuart, 1992; Bigland-Ritchie, 1993).

Concurrently with PAP and "muscle wisdom" muscular fatigue occurs after both MVC-30 s and $50 \%$ MVC- 60 s. A prolonged duration of intense contraction $(10-60 \mathrm{~s})$ induces a substantial disturbance of metabolic profile causing the metabolic fatigue (Green, 1997; Sahlin et al., 1998). An increase in ADP and $\mathrm{P}_{\mathrm{i}}$ (Westerblad et al., 2002) occurs with a concomitant decrease in concentration of ATP and PCr (Houston, Grange, 1990). The consequence of these metabolic alterations is a reduction of free $\mathrm{Ca}^{2+}$ concentration in response to action potential (Westerblad et al., 1998) and impaired function at the level of cross-bridges (Westerblad et al., 2002), which in turn results in a decrease of contraction force for very low, low and high stimulation frequencies (Fig. 1, 3-4). Restoration of metabolic homeostasis following the exercise occurs within the range of minutes and is concomitant with rapid recovery of contractility (Houston, Grange, 1990). Therefore, P 1 and $\mathrm{P} 10$ increases even more compared to post-exercise value, since PAP may persist for longer then 3 min (O'Leary et al., 1997; Baudry, Duchateau, 2004) (Fig. 1, 3).

The inactivation of MVC (Fig. 5) could originate from the inhibition of spinal motoneurons (Behm et al., 2004). Metabolites reduce the mechanical thresholds of group III and IV afferents
(Loring, Hershenson, 1992). Since they have little background discharge and their presence is both widespread and dense, group III and IV afferents can have massive increases in their input to the central nervous system (Gandevia, 1998). Thus, the perception by the central nervous system of fatigue-induced metabolic disruptions can be effectively transmitted to the motoneuron. Moreover, indirect evidence indicates that Ia afferents from intrafusal stretch receptors can contribute up to $30 \%$ of the motoneuron excitation with sustained fatiguing isometric contractions (Gandevia, 1998). Yet if the contraction is sustained for more than $1-2 \mathrm{~s}$ with the development of fatigue, discharge frequency diminishes (Gandevia, 1998). The resulting disfacilitation of motoneurons, while not providing direct inhibition, may decrease motoneuron excitability. Hence, it is possible to have muscle potentiating effects and voluntary force decrements concurrently. In addition, Linnamo et al. (1998) showed that central fatigue was increased with higher exercise intensity; therefore MVC force recovery after MVC-30 s can be slower (Fig. 5).

During 50\% MVC-60 s exercise, the task could be performed without activating all motor units. This suggests that some motor units during $50 \%$ MVC-60 s were not activated or had time to recover, which could affect the faster recovery of P 50 (Fig. 4) and MVC (Fig. 5) force compared with MVC-30 s, when presumably all motor units were activated.

There were no significant changes in $\mathrm{EMG}_{\mathrm{rms}}$ amplitude at $1 \mathrm{~min}$ after both exercises when P 1 and P 10 were potentiated (Fig. 6). These divergent changes in $\mathrm{EMG}_{\mathrm{rms}}$ and potentiation of $\mathrm{P} 1$ and $\mathrm{P} 10$ (Figs. 1, 3) suggest that different processes control increases in $\mathrm{EMG}_{\mathrm{rms}}$, potentiation of force for very low and low stimulation frequencies, and fatigue of tetanic force (Fig. 4). This observation indicates that the mechanisms for potentiation is located beyond the muscle cell membrane and do not involve changes in the ECC. The finding, that $\mathrm{EMG}_{\mathrm{rms}}$ amplitude after $50 \%$ MVC- $60 \mathrm{~s}$ at 3 min was significantly reduced indicates the more efficient changes in muscle contractile characteristics after $50 \%$ MVC-60 s (Fig. 6).

Summing up, simultaneous PAP, "muscle wisdom" and fatigue in quadriceps after both MVC- $30 \mathrm{~s}$ and $50 \%$ MVC-60 s were observed. The primary observations which present evidence for coexistence of fatigue and potentiation are the 
depressed MVC and high-frequency responses while the P 1 is enhanced. Furthermore, the more intensively exercise is performed, the more PAP offsets fatigue straight after exercise. Thus, if elements associated with fatigue such as increased $P_{i}$ were attenuating force output, their effects were easily masked by mechanisms of force potentiation at least during the first 3 min after MVC-30 s and 50\% MVC-60 s exercises.

\section{CONCLUSION}

Coexistence of post-activation potentiation and fatigue when performing exercises with the same amount of work depends on exercise intensity. The more intensive exercise is, the more potentiation counteracts fatigue immediately after exercise; while after submaximal exercise post-activation potentiation becomes more evident only during the recovery period.

\section{REFERENCES}

Baudry, S., Duchateau, J. (2004). Postactivation potentiation in human muscle is not related to the type of maximal conditioning contraction. Muscle \& Nerve, 30, $328-336$.

Behm, D. G., Button, D. C., Barbour, G., Butt, J. C. Young, W. B. (2004). Conflicting effects of fatigue and potentiation on voluntary force. Journal of Strength and Conditioning Research, 18, 2, 365-372.

Bigland-Ritchie, B., Johansson, R., Lippold, O. C. J., Smith, S., Woods, J. J. (1983). Changes in motoneurone firing rates during sustained maximal voluntary contractions. Journal of Physiology, 340, 335-346.

Bigland-Ritchie, B. (1993). Regulation of motorneuron firing rates in fatigue. In: A. J. Sargeant, D. Kernell (Eds.), Neuromuscular fatigue. Amsterdam: Royal Netherlands Academy of Arts and Sciences. P. 147-155.

Cady, E. B., Elshove, H., Jones, D. A., Moll, A. (1989). The metabolic causes of slow relaxation in fatigued human skeletal muscle. Journal of Physiology, 418, 327-337.

Enoka, R. M., Stuart, D. G. (1992). Neurobiology of muscle fatigue. Journal of Applied Physiology, 72, 16311648.

Gandevia, S. C. (1998). Neural control in human muscle fatigue: Changes in muscle afferents, moto neurones and moto cortical drive. Acta Physiologica Scandinavica, 162, $275-283$.

Gollnick, P. D., Karlsson, J., Piehl, K., Saltin, B. (1974). Selective glycogen depletion in skeletal muscle fibres of man following sustained contractions. Journal of Physio$\log y, 241,59-67$.

Green, H. J. (1997). Mechanisms of muscle fatigue in intense exercise. Journal of Sports Sciences, 15, 247256.

Hamada, T., Sale, D. G., MacDougall, J. D., Tarnopolsky, M. A. (2000). Postactivation potentiation, fiber type, and twitch contraction time in human knee extensor muscles. Journal of Applied Physiology, 88, 2131-2137.

Houston, M. E., Grange, R. W. (1990). Myosin phosphorylation, twitch potentiation, and fatigue in human skeletal muscle. Canadian Journal of Physiology and Pharmacology, 68, 908-913.

O’Leary, D. D., Hope, K., Sale, D. G. (1997). Posttetanic potentiation of human dorsiflexors. Journal of Applied Physiology, 83, 2131-2138.

Linnamo, V. Hakkinen, K., Komi, P. V. (1998). Neuromuscular fatigue and recovery in maximal compared to explosive strength loading. European Journal of Applied Physiology and Occupational Physiology, 77, 1-2, $176-181$.

Loring, S. H., Hershenson, M. B. (1992). Effects of series compliance on twitches superimposed on voluntary contractions. Journal of Applied Physiology, 73, 516-521.

MacIntosh, B. R., Gardiner, P. F. (1987). Posttetanic potentiation and skeletal muscle fatigue: Interactions with caffeine. Canadian Journal of Physiology and Pharmacology, 65, 260-268.

Marsden, C. D., Meadows, J. C., Merton, P. A. (1983). "Muscular wisdom" that minimizes fatigue during prolonged effort in man: Peak rates of motoneuron discharge and slowing of discharge during fatigue. Advances in Neurology, 39, 169-211.

Masiulis, N., Skurvydas, A., Kamandulis, S., Kamanduliene, L. (2006). Post-activation potentiation counteracts low-frequency fatigue of quadriceps muscle during explosive strength training session. Ugdymas. Küno kultūra. Sportas, 4 (63), 76-82.

Mathiadden, S. E., Winkel, J. (1990). Electromyographic activity in the shoulder-neck region according to arm position and glenohumeral torque. European Journal of Applied Physiology and Occupational Physiology, 61, 370-379.

Moore, R. L., Stull, J. T. (1984). Myosin light chain phosphorylation in fast and slow skeletal muscles in situ. American Journal of Physiology, 247, C 462-471.

Rankin, L. L., Enoka, R. M., Volz, K. A., Stuart, D. G. (1988). Coexistence of twitch potentiation and tetanic force decline in rat hindlimb muscle. Journal of Applied Physiology, 65, 2687-2695.

Ratkevicius, A., Skurvydas, A., Lexell, J. (1995). Submaximal-exercise-induced impairment of human muscle to develop and maintain force at low frequencies of electrical stimulation. European Journal of Applied Physiology and Occupational Physiology, 70, 294-300.

Rutherford, O. M., Jones, D. A., Newham, D. J. (1986). Clinical and experimental application of the percutaneous twitch superimposition technique for the study of human muscle activation. Journal of Neurology, Neurosurgery, and Psychiatry, 49, 1288-1291.

Sahlin, K., Tonkonogi, M., Soderlund, K. (1998). Energy supply and muscle fatigue in humans. Acta Physiologica Scandinavica, 162, 261-266.

Skurvydas, A., Zachovajevas, P. (1998). Is post-tetanic potentiation, low frequency fatigue (LFF) and post-con- 
tractile depression (PCD) coexistent in intermittent isometric exercises of maximal intensity? Acta Physiologica Scandinavica, 164, 127-133.

Vandenboom, R., Houston, M. E. (1996). Phosphorylation of myosin and twitch potentiation in fatigued skeletal muscle. Canadian Journal of Physiology and Pharmaco$\log y, 74,1315-1321$.

Vandervoort, A. A., Quinlan, J., McComas, A. J. (1983).
Twitch potentiation after voluntary contraction. Experimental Neurology, 81, 141-152.

Westerblad, H., Allen, D. G, Bruton, J. D., Andrade, F. H., Lannergren, J. (1998). Mechanisms underlying the reduction of isometric force in skeletal muscle fatigue. Acta Pphysiologica Scandinavica, 162, 253-260.

Westerblad, H., Allen, D. G., Lannergren, J. (2002). Muscle fatigue: Lactic acid or inorganic phosphate the major cause? News in Physiological Sciences, 17, 17-21.

\title{
KETURGALVIO ŠLAUNIES RAUMENS POSTAKTYVACINE் POTENCIACIJA IR NUOVARGIS ATLIKUS NENUTRŪKSTAMĄ MAKSIMALAUS IR SUBMAKSIMALAUS INTENSYVUMO KRŪVI
}

\author{
Nerijus Masiulis, Albertas Skurvydas, Sigitas Kamandulis, Jūratė Kudirkaitė, Vytautas Sukockas, \\ Edmundas Valys, Vilma Jurevičienè, Lina Kamandulienè
}

Lietuvos kūno kultūros akademija, Kaunas, Lietuva

\section{SANTRAUKA}

Kuris iš fenomenų - raumenų nuovargis ar postaktyvacinè potenciacija (PAP) - bus vyraujantis, priklauso nuo fizinio krūvio tipo, intensyvumo, trukmès ir poilsio laiko tarp stimulų trukmès. Žinoma, kad PAP silpnèja mažèjant fizinio krūvio intensyvumui, tačiau kaip PAP ir nuovargis veikia griaučiu raumenu savybes atliekant skirtingo intensyvumo, bet tokios pačios apimties darbą, nėra aišku. Todèl svarbu nustatyti PAP ir nuovargio poreiški atlikus $30 \mathrm{~s}$ maksimaluji ir $60 \mathrm{~s}$ submaksimaluji, bet tokios pačios apimties nenutrūkstamą krūvị.

Buvo tiriami sveiki aktyviai nesportuojantys vyrai (amžius $23-27 \mathrm{~m}$., svoris $-83,5 \pm 5,4 \mathrm{~kg}$ ) $(\mathrm{n}=11)$. Tiriamieji atliko $30 \mathrm{~s}$ maksimaluji (MVC-30 s) ir $60 \mathrm{~s}$ submaksimaluji krūvi, t. y. naudodami $50 \%$ pastangu (50\% MVC-60 s) koją tiese per kelio sanarị. Darytina prielaida, kad abiejų krūvių metu atlikto darbo apimtis buvo vienoda. Krūviai atlikti atsitiktine tvarka. Keturgalvio šlaunies raumens susitraukimo jèga, sukelta 1 (P 1), 10 (P 10), 20 (P 20) ir 50 (P 50) Hz stimuliavimo dažniu, raumens susitraukimo (CT) ir atsipalaidavimo iki pusès jègos P $1(1 / 2 \mathrm{RT})$ trukmè ir $\mathrm{EMG}_{\mathrm{rms}}$ buvo registruojami iš karto atlikus krūvi (0 min) ir praejus 1, 2 ir 3 min po jo.

P 1 jèga užregistruota iš karto po $(0 \mathrm{~min})$ ir praejjus $1 \mathrm{~min}$ po MVC-30 s krūvio buvo didesnè, lyginant su reikšmemis po $50 \%$ MVC-60 s krūvio $(\mathrm{p}<0,05)$. P 1 susitraukimo laikas $(\mathrm{CT})$ nepakito per 3 min atsigavimo laikotarpi, tačiau P 1 atsipalaidavimo iki pusès jègos (1/2 RT) trukmè labiau pailgèjo iš karto po $50 \%$ MVC$60 \mathrm{~s}$ nei po MVC-30 s krūvio $(\mathrm{p}<0,05)$. Iškart po MVC-30 s krūvio $(0$ min) ir praèjus 1 min $\mathrm{P} 10$ jèga po buvo reikšmingai didesnè ( $<<0,05$ ), palyginti su 50\% MVC-60 s. Jokio skirtumo tarp MVC-30 s ir 50\% MVC-60 s krūvių nenustatyta stimuliuojant raumenis dideliais stimuliavimo dažniams, testuojant MVJ ir $\mathrm{EMG}_{\mathrm{rms}}$ atsigavimo metu.

Postaktyvacinès potenciacijos ir nuovargio sąveika atliekant tokios pačios apimties fizini krūvị, priklauso nuo krūvių intensyvumo. Kuo intensyviau atliekamas fizinis krūvis, tuo labiau potenciacija paslepia nuovargị iškart atlikus krūvị. Atlikus submaksimalų fizinį krūvị potenciacija labiau išryškèja per atsigavimo laikotarpi.

Raktažodžiai: griaučių raumenys, izometrinis krūvis, maksimalioji valinga jèga, atsigavimas.

Gauta 2007 m. birželio 5 d.

Received on June 5, 2007

Priimta $2007 \mathrm{~m}$. rugsėjo $19 \mathrm{~d}$.

Accepted on September 19, 2007
Nerijus Masiulis

Lithuanian Academy of Physical Education

(Lietuvos kūno kultūros akademija)

Sporto str. 6, LT-44221 Kaunas

Lithuania (Lietuva)

Tel +370600 39099

E-mailn.masiulis@lkka.lt 